\title{
Convenient Synthesis of 2-Thioimidazolone/Menadione Conjugates via a Two-Step Sequence Starting with Direct Amination of Menadione
}

\author{
Dmitry A. Guk* (D) \\ Olga O. Krasnovskaya \\ Nikolai V. Zyk \\ Elena K. Beloglazkina
}

Chemistry Department of Lomonosov Moscow State University, 119991, Moscow, Russian Federation

dmh200949@gmail.com

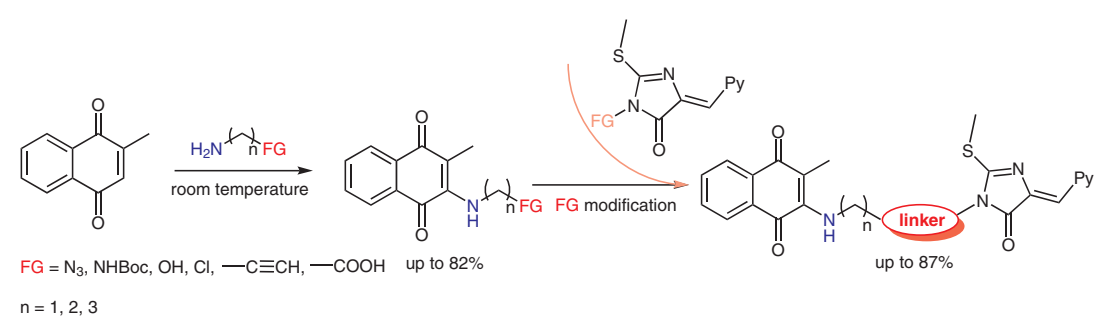

Received: 09.04.2020

Accepted after revision: 21.04 .2020

Published online: 20.05 .2020

DOI: 10.1055/s-0040-1707519; Art ID: so-2020-d0012-I

License terms: (c) $9 \$$

( ) 2020. The Author(s). This is an open access article published by Thieme under the terms of the Creative Commons Attribution-NonDerivative-NonCommercial-License, permitting copying and reproduction so long as the original work is given appropriate credit. Contents may not be used for commercial purposes or adapted, remixed, transformed or built upon. (https://creativecommons.org/licenses/by-nc-nd/4.0/)

Abstract A convenient route to conjugates of 2-thiohydantoins and menadione with linkers of various chemical nature through a two-stage reaction sequence (direct amination of the menadione with a functional amine followed by modification of a functional group) is presented. Optimal conditions for the direct amination of menadione using alkyl amines with substituents such as azide, alkyne, hydroxyl, amine, halogen, and carboxyl have been developed. Further modification of selected functionalities using CUAAC or esterification reactions with 2-thiohydantoines has been performed.

Key words quinone, direct amination, 2-thio-imidazol-4-ones, click chemistry

The search for cytotoxic coordination compounds of biogenic metals, which have lower overall toxicity compared to clinically used platinum-containing drugs, has attracted significant interest in recent years. ${ }^{1,2}$ Among the studied compounds of biogenic transition metals $(\mathrm{Co}, \mathrm{Cu}$, $\mathrm{Zn}, \mathrm{Fe}$ ), the most promising as anticancer agents may be copper coordination compounds, which can exhibit high cytotoxic activity by various mechanisms. ${ }^{3-10}$ Coppercontaining complexes with 2-thio-imidazol-4-ones are among the classes of such compounds with proven antitumor activity, ${ }^{11,12}$ and ability to inhibit telomerase activity. ${ }^{13}$

It is known that coordination compounds containing $\mathrm{Cu}(\mathrm{I})$ can effectively penetrate tumor cells. ${ }^{14}$ Improving drug penetration into cells allows a reduction of their therapeutic dose and, therefore, general toxicity. One strategy to stabilize $\mathrm{Cu}(\mathrm{I})$ in molecules is to use an organic ligand with a redox potential close to $E_{\mathrm{Cu}(\mathrm{II}) / \mathrm{Cu}(\mathrm{I})}$. In this way, we have previously shown that the copper-containing coordination compounds of 2-thioimidazol-4-ones with ferrocenecontaining organic ligands had cytotoxicity comparable to clinically used drugs. ${ }^{15}$ To find the an optimal redox-active fragment to achieve maximum cytotoxicity, we synthesized three novel 2-thioimidazol-4-ones containing organic ligands possessing the 2-methylnaphthalene-1,4-dione (menadione) fragment, instead of the previously utilized bulky ferrocene moiety.

Menadione (2-methyl naphthoquinone) is available from natural sources, in particular from the leaves and nuts of Juglans nigra and Juglans regia. ${ }^{16}$ It has near to the $E_{\mathrm{Cu}(\mathrm{II}) / \mathrm{Cu}(\mathrm{I})}$ potential of quinone/hydroquinone redox transition $\left(E^{0}=+0.2 \mathrm{~V}\right)^{17}$ and can potentially facilitate the intercalation into tumor cell DNA due to its planar $\pi$-system. In addition, a recent study of 1,4-naphthaquinone derivatives has shown that these compounds are selective natural inhibitors of Cdc25 and MKK7, which are key enzymes in the cell cycle and oncogenesis, with inhibition constants in the order of $100 \mathrm{nM},{ }^{18}$ which could lead to an additional enhancement of the antiproliferative effect of menadione conjugates on cancer cells.

To our surprise, examination of the published methods for incorporating an amine fragment into the menadione substrate revealed that there are no protocols for the direct amination of this quinone with primary amines under mild conditions. Menadione reactions with methylamine in a wide range of solvents have been reported, but the yields do not exceed 30-40\%. In particular, the simplest protocol (dichloromethane, $28^{\circ} \mathrm{C}, 24$ hours) leads to the adduct of menadione and methylamine in a yield of $40 \% .{ }^{19}$ Use of ethanol as solvent and a ten-fold excess of amine in the presence of sodium hydroxide for 24 hours gave an increased yield, but complicated the isolation and purification of the product. ${ }^{20}$ Further attempts to increase the yield of the amination 
product required in use of harsher conditions, including reaction in $\mathrm{HClO}_{4}$ medium without organic solvent. ${ }^{21}$ However, such conditions are incompatible with amines possessing labile functional groups.

Two- and three-stage syntheses have also been developed, involving the halogenation of menadione followed by the replacement of the halogen atom with an amine; however, these approaches also resulted in low yields and led to mixtures of halogen substitution, methyl substitution, and polyamination products, even when the simplest amine, methylamine, was used. ${ }^{22}$ In the case of more complex amines the problem of side reactions increased and isolation of the target products was difficult. ${ }^{23}$

However, some methods are known for the amination of menadione and other quinones with simple amines (propyl, butylamine, etc.), as well as branched non-functional amines (tert-butylamine, neopentylamine, etc.). ${ }^{24}$ Using propargylamine as a simple functionalized amine, it was shown that direct amination in alcohol media could result in yields up to $80 \%$. However, the authors of this article also did not extend their finding to more complex and functional amines. ${ }^{25}$

To obtain the desired target compounds, we have developed a two-step synthesis including the direct amination of menadione with functionalized primary alkyl amines under mild conditions, followed by conjugation of the obtained menadione derivatives with substituted 5-pyrididylmethylene-2-thioimidazol-4-ones.

We began our investigation of the menadione amination at room temperature with propargylamine as a simple functionalized primary amine (Table 1 ). A range of polar and nonpolar solvents were tested (DCM, DCM/EtOH mixture, EtOH, DMF) and it was found that the yields in polar media were somewhat higher than in nonpolar ones, and the highest yield was observed when $95 \%$ ethanol was used as a solvent. The optimal reaction time was 9 to 12 hours. With a further increase in time, the yield of the target product increased slightly, but significant amounts of polymeric material were formed.

Carrying out the reaction under an inert atmosphere did not lead to an increase in the yield or to less darkening of the reaction mixture. In contrast, carrying out the reaction in the dark is important, although this was not mentioned in any previous reports on the amination of menadione and its derivatives. Apparently, due to the photooxidation of menadione, ${ }^{26}$ higher yields can be obtained in the absence of light.

All subsequent reactions with substituted amines (Table 2 ) were carried out under the optimized conditions. It was found that the conditions were suitable for primary amines with various functional groups (azide, alkyne, hydroxyl, amine, halogen) and even for glycine. Most reactions proceeded in good yield (up to 82\%). Thus, we have developed a
Table 1 Optimization of the Reaction Conditions ${ }^{\mathrm{a}}$

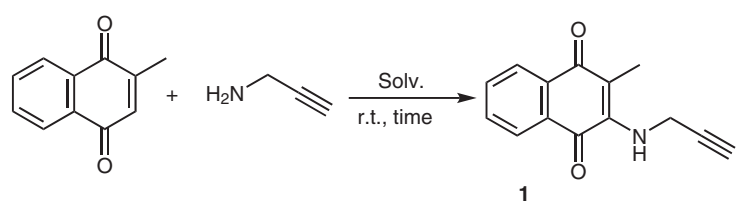

\begin{tabular}{llll}
\hline Entry & Solvent & Time (h) & Yield (\%) \\
\hline 1 & DCM & 3 & 24 \\
2 & DCM/EtOH 10:1 & 3 & 28 \\
3 & DCM/EtOH 1:1 & 3 & 35 \\
4 & EtOH & 3 & 45 \\
5 & DMF & 3 & 30 \\
6 & EtOH 95\% & 6 & 63 \\
7 & EtOH 95\% & 9 & 75 \\
8 & EtOH 95\% & 12 & 80 \\
9 & EtOH 95\% & 24 & 84 \\
10 & EtOH (argon atm.) & 12 & 77 \\
11 & EtOH 95\%(sunlight) & 12 & 49 \\
\hline
\end{tabular}

${ }^{\text {a }}$ All reactions were performed using menadione $(0.3 \mathrm{mmol})$ and propargylamine $(0.9 \mathrm{mmol})$ in solvent $(10 \mathrm{~mL})$ in the absence of light. b Yields calculated based on purified product.

convenient method for the addition of $\mathrm{N}$-nucleophiles to menadione that is suitable for primary amines with various functional groups.

Table 2 Direct Amination of Menadione ${ }^{\mathrm{a}}$

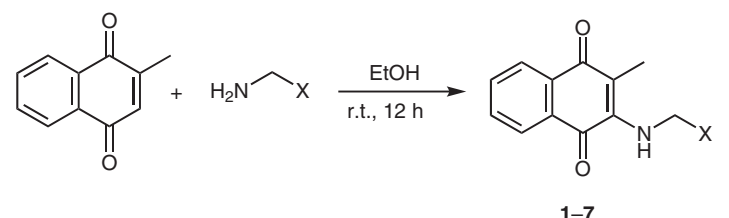

\begin{tabular}{lllll}
\hline Entry & Product & X & Yield $(\%)^{\mathrm{b}}$ & m.p. $\left({ }^{\circ} \mathrm{C}\right)$ \\
\hline 1 & $\mathbf{1}$ & $-\mathrm{C} \equiv \mathrm{CH}$ & 80 & 156 \\
2 & $\mathbf{2}$ & $-\mathrm{CH}_{2}-\mathrm{OH}$ & 73 & 98 \\
3 & $\mathbf{3}$ & $-\mathrm{CH}_{2}-\mathrm{N}_{3}^{\mathrm{c}}$ & 82 & 100 \\
4 & $\mathbf{4}$ & $-\mathrm{CH}_{2}-\mathrm{CH}_{2}-\mathrm{N}_{3}^{\mathrm{c}}$ & 80 & 58 \\
5 & $\mathbf{5}$ & $-\mathrm{CH}_{2}-\mathrm{CH}_{2}-\mathrm{NHBoc}_{2}$ & 57 & 106 \\
6 & $\mathbf{6}$ & $-\mathrm{CH}_{2}-\mathrm{Cl}_{2}$ & 78 & 123 \\
7 & $\mathbf{7}$ & $-\mathrm{CH}_{2}-\mathrm{COOH}^{\mathrm{d}}$ & 64 & 174 \\
\hline
\end{tabular}

a All reactions were performed under the optimized conditions.

b Yields calculated based on purified product.

c Azidoamines were prepared by the procedure previously reported for

2 -azidoethanamine and used without purification. ${ }^{15}$

${ }^{d}$ Triethylamine was added to form the free $\mathrm{NH}_{2}$ group from the zwitterion.

It should be noted that 2-azidoethanamine and 3-azidopropan-1-amine are both reasonably stable and safe to use either in solution or as neat materials when cooled to 
$0-10{ }^{\circ} \mathrm{C}$, so they should be added cold. The relatively low yield in the case of product 5 may be explained by increased polymerization in this case.

A comparison of the UV/Vis spectra of target and starting compounds (Figure 1) showed that compounds 1-6 have an absorption maximum of about $450 \mathrm{~nm}$, which is consistent with their intense red color, and such adsorption bands are distinct from the absorption band of the initial menadione (absorption maximum at $332 \mathrm{~nm}$, yellow color). The extinction coefficients for all amino-menadiones 1-7 are approximately $2-3 \times 10^{3} \mathrm{M}^{-1} \mathrm{~cm}^{-1}$. The positions of the absorption maxima are slightly dependent on the nature of the functional group in the amine and on the length of the hydrocarbon spacer between the functional group and the amino group. The combination of these factors allows assessment of the progress of the menadione amination to be made visually, by observing the change in color of the reaction mixture from yellow to bright red.

Thus, UV/Vis spectroscopy may be used for the determination of the product concentrations in mixtures and in biological tests.

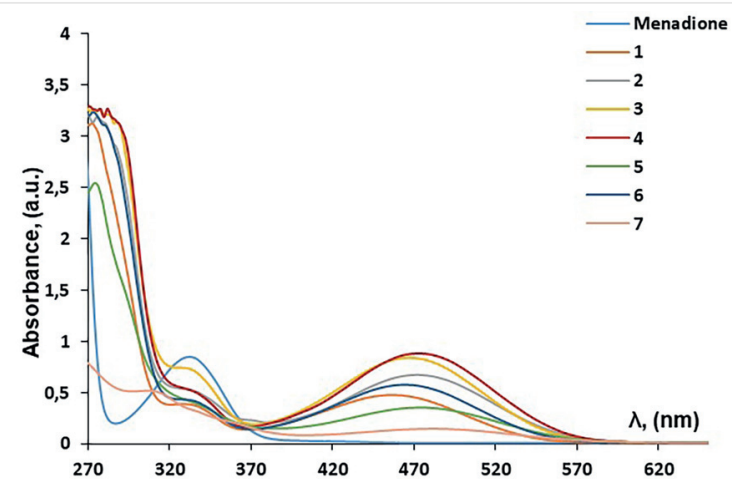

Figure $1 \mathrm{UV} / \mathrm{Vis}$ spectra of menadione and compounds 1-7 (EtOH, $3 \times$ $\left.10^{-4} \mathrm{M}\right)$.

Compounds 1-7 may then potentially be used to incorporate a menadione fragment into the structure of different organic ligands via linkers of various chemical nature using azide-alkyne cycloaddition reactions, ester and peptide synthesis, and also by nucleophilic substitution of a labile halogen (chlorine) atom.

To demonstrate the feasibility of such reactions, the products of the azide-alkyne cycloaddition (CuACC) of menadione derivatives $\mathbf{1}$ and $\mathbf{3}$ with azido- and alkynylcontaining 5-pyridylmethylene-2-thio-imidazolones $\mathbf{8}$ and 9 were synthesized (Scheme 1). As a result, menadionesubstituted derivatives $\mathbf{1 1}$ and $\mathbf{1 2}$ were obtained in high yields under heterogeneous click reaction conditions.

For the synthesis of organic ligands by click chemistry, it was important to test the reactivity of azides and alkynes under the conditions of biphasic catalysis with $\mathrm{Cu}(\mathrm{I})$. Carrying out the reactions in a methylene chloride/water mixture avoided the loss of catalyst by binding to the chelating part of the ligand and reduced the difficulties associated with isolating the free product (not bound to copper ions) from the reaction mixture. Washing the excess copper from the by-product complex with EDTA and other complexants created additional preparative difficulties due to the low solubility of the copper complexes of the 2-thiohydantoins in water and the hydrolysis of the SME fragments. Previously described click reactions of menadione derivatives were mostly carried out under homogeneous conditions, which were not applicable in our case..$^{25,27-31}$

It is worthy of note that both aminomenadiones $\mathbf{1}$ and $\mathbf{3}$ with propargyl and azide moieties are equally effective under these reaction conditions.

The conjugate 13, containing menadione and 2-thioimidazole-4-one moieties linked via a biodegradable ester linker, was synthesized starting from hydroxy-containing quinone 2 and $(Z)-2-(5-0 x 0-4$-(pyridin-2-ylmethylidene)2-thioxoimidazolin-1-yl) acetic acid (10; Scheme 2).

It was shown that the hydroxy-containing menadione derivative $\mathbf{2}$ is not only capable of being applied to carbodiimide synthesis, but it also gave satisfactory yields of the target ester under standard reaction conditions and with standard combinations of activating reagents without additional optimization.<smiles>C#CCNC1=C(C)C(=O)c2ccccc2C1=O</smiles>

Scheme 1 CuACC reactions of menadione derivatives $\mathbf{1}$ and $\mathbf{3}$ with 5-pyridylmethylene-2-thioimidazolones $\mathbf{8}$ and $\mathbf{9}$ 


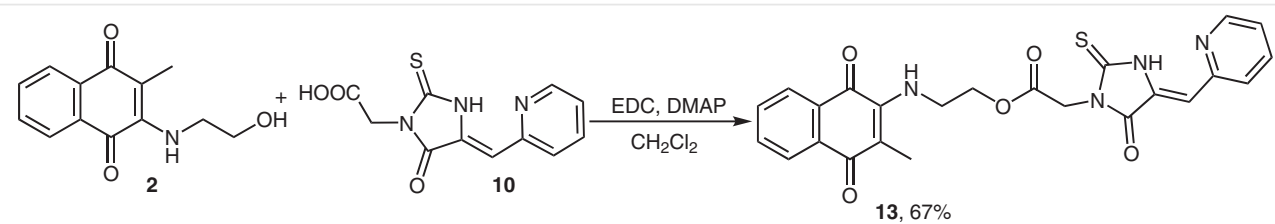

Scheme 2 Synthesis of conjugate 13 with an ester linker between menadione- and 2-thioimidazole-4-one-containing fragments

In conclusion, in the framework of this work, various conditions for the direct amination of menadione have been investigated, optimal conditions were selected for the case of labile amines, and a series of aminated derivatives was obtained with $60-80 \%$ yields. ${ }^{32-36}$ The possibility of further conjugation of the obtained menadione functional derivatives containing propargyl, azide or hydroxyl fragments with substituted 5-pyridylmethylene-2-thioimidazol-4ones has been demonstrated. All products were isolated and purified using column chromatography with reasonable yields. Thus, a convenient synthetic pathway for accessing conjugates of 2-thioimidazol-4-ones and menadione with various linkers based on a two-step procedure, which opens up the possibility of obtaining a wide series of promising ligands for antitumor coordination compounds, has been developed.

\section{Funding Information}

This work was supported by the Russian Foundation for Basic Research (project no. 19-33-90103).

\section{Acknowledgment}

We acknowledge support from M.V. Lomonosov Moscow State University Program of Development for providing an Agilent 400-MR NMR spectrometer. The authors are grateful to Thermo Fisher Scientific Inc., Textronica AG group (Moscow, Russia), and personally to Prof. Alexander Makarov for providing access to an Orbitrap Elite mass spectrometer for this work.

\section{Supporting Information}

Supporting information for this article is available online at https://doi.org/10.1055/s-0040-1707519.

\section{References and Notes}

(1) Gaál, A.; Orgován, G.; Mihucz, V. G.; Pape, I.; Ingerle, D.; Streli, C.; Szoboszlai, N. J. Trace Elem. Med. Biol. 2018, 47, 79.

(2) Dabrowiak, J. C. Metals in Medicine; Wiley: Weinheim, 2009, 49-249.

(3) Xin, C.; Xiaolan, Z.; Jinghong, C.; Qianqian, Y.; Li, Y.; Dacai, X.; Peiquan, Z.; Xuejun, W.; Jinbao, L. Eur. J. Pharmacol. 2017, 815, 147.
(4) Zeeshan, M.; Murugadas, A.; Ghaskadbi, S.; Rajendran, R. B.; Akbarsha, M. A. Comp. Biochem. Physiol., Part C: Toxicol. Pharmacol. 2016, 185, 1.

(5) Qin, Q.-P.; Meng, T.; Tan, M.-X.; Liu, Y.-C.; Luo, X.-J.; Zou, B.-Q.; Liang, H. Eur. J. Med. Chem. 2018, 143, 1597.

(6) Hernandes, M. S.; Britto, L. R. Curr. Neuropharmacol. 2012, 10, 321.

(7) Fatfat, M.; Merhi, R. A.; Rahal, O.; Stoyanovsky, D. A.; Zaki, A.; Haidar, H.; Kagan, V. E.; Gali-Muhtasib, H.; Machaca, K. BMC Cancer 2014, 14, 527.

(8) Kremer, M. L. Phys. Chem. Chem. Phys. 1999, 1, 3595.

(9) Sangeetha, S.; Murali, M. Int. J. Biol. Macromol. (Part B) 2018, $107,2501$.

(10) Martinez-Bulit, P.; Garza-Ortíz, A.; Mijangos, E.; Barrón-Sosa, L.; Sánchez-Bartéz, F.; Gracia-Mora, I.; Flores-Parra, A.; Contreras, R.; Reedijk, J.; Barba-Behrens, N. J. Inorg. Biochem. 2015, 142, 1.

(11) Beloglazkina, E. K.; Krasnovskaya, O. O.; Guk, D. A.; Tafeenko, V. A.; Moiseeva, A. A.; Zyk, N. V.; Majouga, A. G. Polyhedron 2018, $148,129$.

(12) Tishchenko, K.; Beloglazkina, E.; Proskurnin, M.; Malinnikov, V.; Guk, D.; Muratova, M.; Krasnovskaya, O.; Udina, A.; Skvortsov, D.; Shafikov, R. R.; Ivanenkov, Y.; Aladinskiy, V.; Sorokin, I.; Gromov, O.; Majouga, A.; Zyk, N. J. Inorg. Biochem. 2017, 175, 190.

(13) Majouga, A. G.; Zvereva, M. I.; Rubtsova, M. P.; Skvortsov, D. A.; Mironov, A. V.; Azhibek, D. M.; Krasnovskaya, O. O.; Gerasimov, V. M.; Udina, A. V.; Vorozhtsov, N. I.; Beloglazkina, E. K.; Agron, L.; Mikhina, L. V.; Tretyakova, A. V.; Zyk, N. V.; Zefirov, N. S.; Kabanov, A. V.; Dontsova, O. A. J. Med. Chem. 2014, 57, 6252.

(14) Ren, F.; Logeman, B. L.; Zhang, X.; Liu, Y.; Thiele, D. J.; Yuan, P. Nat. Commun. 2019, 10, 1386.

(15) Guk, D. A.; Krasnovskaya, O. O.; Dashkova, N. S.; Skvortsov, D. A.; Rubtsova, M. P.; Dyadchenko, V. P.; Yudina, E. S.; Kosarev, M. A.; Soldatov, A. V.; Shapovalov, V. V.; Semkina, A. S.; Vlasova, K. Y.; Pergushov, V. I.; Shafikov, R. R.; Moiseeva, A. A.; Andreeva, A. V.; Melnikov, M. Y.; Zyk, N. V.; Majouga, A. G.; Beloglazkina, E. K. Dalton Trans. 2018, 17357.

(16) Binder, R. G.; Benson, M. E.; Flath, R. A. Phytochemistry 1989, 28 , 2799.

(17) Nivinskas, H.; Stasskevicciene, S.; Sarlauskas, J.; Koder, R. L.; Miller, A.-F.; Ceenas, N. Arch. Biochem. Biophys. 2002, 403, 249.

(18) Schepetkin, I. A.; Karpenko, A. S.; Khlebnikov, A. I.; Shibinska, M. O.; Levandovskiy, I. A.; Kirpotina, L. N.; Danilenko, N. V.; Quinn, M. T. Eur. J. Med. Chem. 2019, 183, 111719.

(19) Chadar, D.; Camilles, M.; Patil, R.; Khan, A.; Weyhermüller, T.; Salunke-Gawali, S. J. Mol. Struct. 2015, 1086, 179.

(20) Hiramoto, M. Yakugaku Zasshi (J. Pharm. Soc. Jpn.) 1942, 62, 464.

(21) Sharma, U.; Katoch, D.; Sood, S.; Kumar, N.; Singh, B.; Thakur, A.; Gulati, A. Indian J. Chem., Sect. B: Org. Chem. Incl. Med. Chem. 2013, 52, 1431.

(22) Ohta, S.; Hinata, Y.; Yamashita, M.; Kawasaki, I.; Jinda, Y.; Horie, S. Chem. Pharm. Bull. 1994, 42, 1730. 
(23) Schepetkin, I. A.; Karpenko, A. S.; Khlebnikov, A. I.; Shibinska, M. O.; Levandovskiy, I. A.; Kirpotina, L. N.; Danilenko, N. V.; Quinn, M. T. Eur. J. Med. Chem. 2019, 183, 111719.

(24) Wang, M.; Zhang, C.; Sun, L.-P.; Ding, C.; Zhang, A. J. Org. Chem. 2014, 79, 4553.

(25) Jing, L.; Wu, G.; Hao, X.; Olotu, F. A.; Kang, D.; Chen, C. H.; Lee, K.-H.; Soliman, M. E. S.; Liu, X.; Song, Y.; Zhan, P. Eur. J. Med. Chem. 2019, 183, 111696.

(26) Vire, J. C.; Patriarche, G. J.; Christian, G. D. Pharmazie 1980, 35 , 209.

(27) Brandao, C.; Rocha, Missias. F. C.; Arantes, L. M.; Soares, L. F.; Roy, K. K.; Doerksen, R. J.; Braga de Oliveira, A.; Pereira, G. R. Eur. J. Med. Chem. 2018, 145, 191.

(28) da Cruz, E. H.; Hussene, C. M.; Dias, G. G.; Diogo, E. B.; de Melo, I. M.; Rodrigues, B. L.; da Silva, M. G.; Valenca, W. O.; Camara, C. A.; de Oliveira, R. N.; de Paiva, Y. G.; Goulart, M. O.; Cavalcanti, B. C.; Pessoa, C.; da Silva Júnior, E. N. Bioorg. Med. Chem. 2014, 22, 1608.

(29) Bahia, S. B. B. B.; Reis, W. J.; Jardim, G. A. M.; Souto, F. T.; de Simone, C. A.; Gatto, C. C.; Menna-Barreto, R. F. S.; de Castro, S. L.; Cavalcanti, B. C.; Pessoa, C.; Araujo, M. H.; da Silva Júnior, E. N. MedChemComm 2016, 7, 1555.

(30) Prasad, C. V.; Nayak, V. L.; Ramakrishna, S.; Mallavadhani, U. V. Chem. Biol. Drug Des. 2018, 91, 220.

(31) Gholampour, M.; Ranjbar, S.; Edraki, N.; Mohabbati, M.; Firuzi, O.; Khoshneviszadeh, M. Bioorg. Chem. 2019, 88, 102967.

(32) Direct Amination of Menadione; General Procedure: To a stirred solution of menadione ( $100 \mathrm{mg}, 0.6 \mathrm{mmol})$ in EtOH (10 $\mathrm{mL}$ ), primary amine $(1.2 \mathrm{mmol}$ ) was added in one portion. After 12 hours of stirring in the dark, the reaction mixture became dark red. The alcohol was evaporated under reduced pressure, and the residue was dissolved in a mixture of $\mathrm{DCM} / \mathrm{MeOH}$ (30:1) and purified by silica gel column chromatography, eluting with the same solvent system. All products were isolated in the form of bright-red oils that crystallized with difficulty. Crystallization occurred when oils were left standing, giving red powders.

(33) 2-Methyl-3-(prop-2-yn-1-ylamino)naphthalene-1,4-dione (1): From menadione and propargylamine ( $66 \mathrm{mg}, 1.2 \mathrm{mmol}), 1$ was obtained as a bright-orange powder. Yield after purification by column chromatography: $105 \mathrm{mg}(80 \%) ; \mathrm{mp} 156{ }^{\circ} \mathrm{C} .{ }^{1} \mathrm{H}$ NMR $\left(400 \mathrm{MHz}\right.$, DMSO- $\left.d_{6}\right): \delta=7.92(\mathrm{~d}, J=6.85 \mathrm{~Hz}, 2 \mathrm{H}, \mathrm{Ar}), 7.77(\mathrm{t}, J=$ $7.34 \mathrm{~Hz}, 1 \mathrm{H}, \mathrm{Ar}-\mathrm{CO}), 7.69$ (t, $J=7.34 \mathrm{~Hz}, 1 \mathrm{H}, \mathrm{Ar}-\mathrm{CO}), 6.93$ (t, $J=$ $6.85 \mathrm{~Hz}, 1 \mathrm{H}, \mathrm{NH}), 4.28\left(\mathrm{~d}, J=6.85 \mathrm{~Hz}, 2 \mathrm{H}, \mathrm{CH}_{2}\right), 3.25(\mathrm{~s}, 1 \mathrm{H}$, $\mathrm{C} \equiv \mathrm{CH}), 2.15\left(\mathrm{~s}, 3 \mathrm{H}, \mathrm{CH}_{3}\right) .{ }^{13} \mathrm{C}$ NMR $\left(100.67 \mathrm{MHz}\right.$, DMSO- $\left.d_{6}\right): \delta=$ 182.2 (CO), 181.9 (CO), $146.0(\mathrm{C}-\mathrm{NH}), 134.5$ (Ar), 132.4 (Ar), $130.3(\mathrm{Ar}), 125.7(\mathrm{Ar}), 113.3\left(\mathrm{C}-\mathrm{CH}_{3}\right), 82.0(-\mathrm{C} \equiv), 74.6(\equiv \mathrm{CH}), 33.9$ $\left(\mathrm{CH}_{2}\right), 10.19\left(\mathrm{CH}_{3}\right)$. HRMS: $\mathrm{m} / z[\mathrm{M}+\mathrm{H}]^{+}$calcd 226.0863; found. 226.0865. UV/Vis: $\lambda\left(\varepsilon, \mathrm{Lmol}^{-1} \mathrm{~cm}^{-1}\right): 457(1587) \mathrm{nm}$.

2-((2-Hydroxyethyl)amino)-3-methylnaphthalene-1,4-dione (2): From menadione and ethanolamine ( $73 \mathrm{mg}, 1.2 \mathrm{mmol}$ ), 2 was obtained as a deep-violet powder. Yield after purification by column chromatography: $98 \mathrm{mg}(73 \%) ; \mathrm{mp} 98{ }^{\circ} \mathrm{C} .{ }^{1} \mathrm{H}$ NMR $\left(400 \mathrm{MHz}, \mathrm{DMSO}-d_{6}\right): \delta=7.90$ (ddd, $J=7.58,4.4,1.17 \mathrm{~Hz}, 2 \mathrm{H}$, $\mathrm{Ar}), 7.76(\mathrm{td}, J=7.58,1.27 \mathrm{~Hz}, 1 \mathrm{H}, \mathrm{Ar}-\mathrm{CO}), 7.66(\mathrm{t}, J=7.58 \mathrm{~Hz}$, $1 \mathrm{H}, \mathrm{Ar}-\mathrm{CO}), 6.49(\mathrm{t}, J=5.67,1 \mathrm{H}, \mathrm{NH}), 4.90(\mathrm{t}, J=5.09 \mathrm{~Hz}, 1 \mathrm{H}$, $\mathrm{OH}), 3.58\left(\mathrm{~m}, 4 \mathrm{H}, 2 \times \mathrm{CH}_{2}\right), 2.09\left(\mathrm{~s}, 3 \mathrm{H} \mathrm{CH}_{3}\right) .{ }^{13} \mathrm{C} \mathrm{NMR}(100.67$ $\mathrm{MHz}$, DMSO- $d_{6}$ ): $\delta=182.5$ (CO), $182.3(\mathrm{CO}), 147.3(\mathrm{C}-\mathrm{NH}), 134.8$ (Ar), $133.2(\mathrm{Ar}), 132.5(\mathrm{Ar}), 130.6(\mathrm{Ar}), 126.0(\mathrm{Ar}), 125.8(\mathrm{Ar})$, 111.2 $\left(\mathrm{C}-\mathrm{CH}_{3}\right), 60.9\left(\mathrm{CH}_{2}-\mathrm{NH}\right), 47.2\left(\mathrm{CH}_{2}-\mathrm{OH}\right), 11.2\left(\mathrm{CH}_{3}\right)$. HRMS: [M $+\mathrm{H}]^{+}$calcd 232.0968; found: 232.0969 . UV/Vis: $\lambda\left(\varepsilon, \mathrm{Lmol}^{-1}\right.$ $\left.\mathrm{cm}^{-1}\right): 472(2240) \mathrm{nm}$.
2-((2-Azidoethyl)amino)-3-methylnaphthalene-1,4-dione

(3): From menadione and 2-azidoethylamine (103 mg, 1.2 $\mathrm{mmol}), 3$ was obtained as a bright-red powder. Yield after purification by column chromatography: $122 \mathrm{mg}$ (82\%); mp $100{ }^{\circ} \mathrm{C}$ (dec.). ${ }^{1} \mathrm{H}$ NMR (400 MHz, DMSO- $\left.d_{6}\right): \delta=7.92(\mathrm{~d}, J=7.70 \mathrm{~Hz}$, $2 \mathrm{H}, \mathrm{Ar}), 7.78(\mathrm{td}, J=7.47,1.38 \mathrm{~Hz}, 1 \mathrm{H}, \mathrm{Ar}-\mathrm{CO}), 7.69(\mathrm{t}, J=$ $7.47 \mathrm{~Hz}, 1 \mathrm{H}, \mathrm{Ar}-\mathrm{CO}), 6.68(\mathrm{t}, J=6.69,1 \mathrm{H}, \mathrm{NH}), 3.75(\mathrm{q}, J=$ $\left.6.17 \mathrm{~Hz}, 2 \mathrm{H}, \mathrm{NH}-\mathrm{CH}_{2}\right), 3.53\left(\mathrm{t}, J=5.78 \mathrm{~Hz}, 2 \mathrm{H}, \mathrm{CH}_{2}-\mathrm{N}_{3}\right), 2.06(\mathrm{~s}$, $\left.3 \mathrm{H}, \mathrm{CH}_{3}\right) .{ }^{13} \mathrm{C}$ NMR $\left(100.67 \mathrm{MHz}, \mathrm{CDCl}_{3}\right): \delta=183.6(\mathrm{CO}), 182.1$ (CO), 145.7 (C-NH), 135.6 ( $\mathrm{Ar}), 134.3(\mathrm{Ar}), 133.6(\mathrm{Ar}), 132.0(\mathrm{Ar})$, $126.5(\mathrm{Ar}), 126.3(\mathrm{Ar}), 114.0\left(\mathrm{C}-\mathrm{CH}_{3}\right), 51.5\left(\mathrm{CH}_{2}-\mathrm{NH}\right), 44.2$ $\left(\mathrm{CH}_{2}-\mathrm{N}_{3}\right), 11.2\left(\mathrm{CH}_{3}\right)$. HRMS: $\mathrm{m} / z[\mathrm{M}+\mathrm{H}]^{+}$calcd 257.1033; found: 257.1036 . UV/Vis: $\lambda\left(\varepsilon, \mathrm{Lmol}^{-1} \mathrm{~cm}^{-1}\right): 467(2797) \mathrm{nm}$

(34) Click Reactions in $\mathbf{C H}_{\mathbf{2}} \mathbf{C l}_{2} / \mathbf{H}_{\mathbf{2}} \mathbf{O}$; General Procedure: To a solution of alkyne $(0.33 \mathrm{mmol})$ in $\mathrm{CH}_{2} \mathrm{Cl}_{2}(7.5 \mathrm{~mL}), \mathrm{CuSO}_{4} \cdot 5 \mathrm{H}_{2} \mathrm{O}(8$ $\mathrm{mg}, 0.033 \mathrm{mmol})$ dissolved in distilled water $(200 \mu \mathrm{L})$, followed by sodium ascorbate $(14 \mathrm{mg}, 0.066 \mathrm{mmol}$ ) in distilled water $(200 \mu \mathrm{L})$ were added under an argon atmosphere. The mixture was stirred for 30 minutes and the azide $(0.33 \mathrm{mmol})$ in $\mathrm{CH}_{2} \mathrm{Cl}_{2}$ $(2.5 \mathrm{~mL})$ was added to the dark-brown solution. The reaction mixture was then stirred overnight under argon. The reaction mixture was evaporated under reduced pressure and the solid residue was purified by silica gel column chromatography, eluting with $\mathrm{CH}_{2} \mathrm{Cl}_{2} / \mathrm{MeOH}(40: 1)$.

(35) (Z)-2-Methyl-3-(((1-(2-(5-oxo-4-(pyridin-2-ylmethylene)-2thioxoimidazolidin-1-yl)ethyl)-1H-1,2,3-triazol-4-yl)methyl)amino)naphthalene-1,4-dione (11): To 2-methyl-3-(prop-2-yn1-ylamino)naphthalene-1,4-dione (1; $150 \mathrm{mg}, 0.67 \mathrm{mmol})$ in $\mathrm{CH}_{2} \mathrm{Cl}_{2}(7.5 \mathrm{~mL}), \mathrm{CuSO}_{4} \cdot 5 \mathrm{H}_{2} \mathrm{O}(17 \mathrm{mg})$ dissolved in distilled water $(200 \mu \mathrm{L})$, followed by sodium ascorbate $(28 \mathrm{mg})$ in distilled water $(200 \mu \mathrm{L})$ were added under an argon atmosphere. The mixture was stirred for 30 minutes and 5-(Z)-3-(2-azidoethyl)2-(methylthio)-5-(pyridine-2-ylmethylene)- $1 \mathrm{H}$-imidazol- $4 \mathrm{H}$ one $\left(193 \mathrm{mg}, 0.67 \mathrm{mmol}\right.$ ) in $\mathrm{CH}_{2} \mathrm{Cl}_{2}(2.5 \mathrm{~mL})$ was added to the dark-brown solution and the reaction mixture was stirred overnight under argon. The pink precipitate was filtered off, dried in air and purified by silica gel column chromatography, eluting with $\mathrm{CH}_{2} \mathrm{Cl}_{2} / \mathrm{MeOH}$ (40:1). Yield after purification by column chromatography: $299 \mathrm{mg}$ (87\%); $\mathrm{mp} 212{ }^{\circ} \mathrm{C} .{ }^{1} \mathrm{H}$ NMR (400 MHz, $\mathrm{CDCl}_{3}$ ): $\delta=8.71$ (d, $\left.J=8.1 \mathrm{~Hz}, 1 \mathrm{H}, \mathrm{H \alpha}-\mathrm{Py}\right), 8.63(\mathrm{~d}, J=3.91 \mathrm{~Hz}$, $1 \mathrm{H}, \mathrm{H} \gamma$-Py), 8.05 (s, $1 \mathrm{H}, \mathrm{H}$-triazole), 7.88 (m, $2 \mathrm{H}, \mathrm{Ar}$ ), 7.75 (td, $J=7.52,1.1 \mathrm{~Hz}, 1 \mathrm{H}, \mathrm{Ar}), 7.66(\mathrm{~m}, 1 \mathrm{H}, \mathrm{Ar}), 7.34(\mathrm{~m}, 1 \mathrm{H}, \mathrm{H} \beta-\mathrm{Py})$, $7.04(\mathrm{t}, J=6.72 \mathrm{~Hz}, 1 \mathrm{H}, \mathrm{H} \beta$ '-Py), $6.69(\mathrm{~s}, 1 \mathrm{H},-\mathrm{CH}=), 4.78$ (d, $J=$ $\left.6.6 \mathrm{~Hz}, 2 \mathrm{H}, \mathrm{NH}-\mathrm{CH}_{2}-\right), 4.60\left(\mathrm{t}, J=6.6 \mathrm{~Hz}, 2 \mathrm{H},-\mathrm{CH}_{2}-\mathrm{CH}_{2}-\right), 3.95(\mathrm{t}$, $\left.J=5.3 \mathrm{~Hz}, 2 \mathrm{H},-\mathrm{CH}_{2}-\mathrm{CH}_{2}-\right), 2.58\left(\mathrm{~s}, 3 \mathrm{H}, \mathrm{SCH}_{3}\right), 2.07\left(\mathrm{~s}, 3 \mathrm{H}, \mathrm{CH}_{3}\right)$. ${ }^{13} \mathrm{C}$ NMR (100.67 MHz, CDCl $\left.{ }_{3}\right): \delta=168.7$ (CO), 167.7 (CO), 149.9

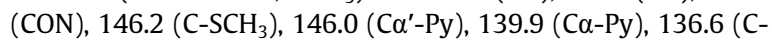
$\mathrm{NH}), 134.4(\mathrm{C} \gamma-\mathrm{Py}), 132.6(\mathrm{CH}=\mathrm{C}<), 132.2(\mathrm{CH}-\mathrm{Ar}), 130.3(\mathrm{CH}-$ $\mathrm{Ar}$ ), 126.5 (C-Ar), 125.7 (C-Ar), 125.5 (-CH=), 123.6 (C-triazole), 123.4 (C-triazole), 121.8 (C $\beta$-Py), 112.1 (C-CH3), 50.3 (N-CH2CH2-), 47.5 (NH-CH2-), 41.4 (N-CH2-CH2-), 12.9 (SCH3), 10.4 (CH3). HRMS: $\mathrm{m} / \mathrm{z}$ [M + H]+ calcd 514.1656; found: 514.1664.

(36) (Z)-2-((3-Methyl-1,4-dioxo-1,4-dihydronaphthalen-2yl)amino)ethyl 2-(5-Oxo-4-(pyridin-2-ylmethylene)-2-thioxoimidazolidin-1-yl)acetate (13): To a stirred solution of (Z)-2-(5oxo-4-(pyridin-2-ylmethylene)-2-thioxoimidazolidin-1-yl)acetic acid $(50 \mathrm{mg}, 0.2 \mathrm{mmol})$ in anhydrous $\mathrm{CH}_{2} \mathrm{Cl}_{2}(20 \mathrm{~mL})$ were added DMAP (12 mg, $0.1 \mathrm{mmol}$ ) and EDC. $\mathrm{HCl}(44 \mathrm{mg}, 0.23$ $\mathrm{mmol}$ ). After stirring for 20 minutes, a solution of 2 ( $60 \mathrm{mg}, 0.26$ $\mathrm{mmol}$ ) in $\mathrm{CH}_{2} \mathrm{Cl}_{2}(3 \mathrm{~mL})$ was added and the reaction mixture was stirred at room temperature overnight. The solvent was evaporated under reduced pressure, and the solid residue was 
purified by silica gel column chromatography, eluting with $\mathrm{CH} 2 \mathrm{Cl} 2 / \mathrm{MeOH}$ (40:1). Yield after purification by column chromatography: $60 \mathrm{mg}(67 \%) ; \mathrm{mp} 196{ }^{\circ} \mathrm{C} .1 \mathrm{H}$ NMR $(400 \mathrm{MHz}$, $\mathrm{CDCl} 3): \delta=8.65$ (d, J = $\left.3.96 \mathrm{~Hz}, 1 \mathrm{H}, \mathrm{H} \alpha^{\prime}-\mathrm{Py}\right), 8.03$ (dd, J = 7.70, $0.95 \mathrm{~Hz}, 1 \mathrm{H}, \mathrm{CH}-\mathrm{Ar}$ ), 7.92 (dd, J = 7.63, $1.03 \mathrm{~Hz}, 1 \mathrm{H}, \mathrm{CH}-\mathrm{Ar}$ ), 7.73 (td, J = 7.70, $\left.1.76 \mathrm{~Hz}, 1 \mathrm{H}, \mathrm{CH}^{\prime}-\mathrm{Ar}\right), 7.63$ (td, J = 7.56, $1.32 \mathrm{~Hz}$, $\left.1 \mathrm{H}, \mathrm{CH}-\mathrm{Ar}^{\prime \prime}\right), 7.53$ (m, $\left.1 \mathrm{H}, \mathrm{H} \beta-\mathrm{Py}\right), 7.38$ (d, J = $7.92 \mathrm{~Hz}, 1 \mathrm{H}, \mathrm{H} \beta^{\prime}-$ Py), 7.24 (m, $1 \mathrm{H}, \mathrm{H} \gamma-\mathrm{Py}), 6.56$ (s, $1 \mathrm{H},-\mathrm{CH}=), 5.72$ (br. s, $1 \mathrm{H}$, $\mathrm{NH}), 4.69$ (s, $2 \mathrm{H}, \mathrm{CH} 2 \mathrm{COO}), 4.37$ (t, J = 5.21 Hz, $2 \mathrm{H}, \mathrm{NH}-\mathrm{CH} 2-)$, $3.83(\mathrm{q}, \mathrm{J}=5.67 \mathrm{~Hz}, 1 \mathrm{H},-\mathrm{CH} 2 \mathrm{CH} 2-), 2.18$ (s, $3 \mathrm{H}, \mathrm{CH} 3) .13 \mathrm{C}$ NMR (100.67 MHz, CDCl3): $\delta=183.5$ (CO), 182.1 (CO), 176.9 (CS), 173.5 (COO), 166.6 (CON), 163.3 ( $\alpha$ C-Py), 153.4 ( $\left.\alpha^{\prime} \mathrm{C}-\mathrm{Py}\right), 149.7$ $(>\mathrm{C}=\mathrm{CH}), 145.9(\mathrm{CH}-\mathrm{NH}), 137.1$ ( $\gamma \mathrm{C}-\mathrm{Py}), 134.1$ ( $\beta \mathrm{C}-\mathrm{Py}), 131.9$ (CH-Ar), 130.4 (C-Ar), 130.0 (C-Ar), 126.5 (CH-Ar), 126.1 (CH$\mathrm{Ar}), 125.9$ (CH-Ar), 123.1 ( $\left.\beta^{\prime} \mathrm{C}-\mathrm{Py}\right), 114.0(-\mathrm{CH}=), 108.9(\mathrm{CH}-$ $\left.\mathrm{CH}_{3}\right), 64.7\left(\mathrm{CH}_{2}-\mathrm{CH}_{2}-\mathrm{COO}\right), 44.0\left(\mathrm{COO}-\mathrm{CH}_{2}-\mathrm{NH}\right), 41.7\left(\mathrm{CH}_{2}-\mathrm{CH}_{2}-\right.$ COO), $11.1\left(\mathrm{CH}_{3}\right)$. HRMS: $m / z$ [M $\left.+\mathrm{H}\right]^{+}$calcd 477.1227; found: 477.1223 . 